\title{
Aplikasi Metode Importancae Performance Analysis dalan Analisa Tingkat Pelyanan Mode Speedboat
}

\author{
Abdul Gaus*1, Chaerul Anwar1, Sutrisno Putra $\mathbf{P}^{2}$ \\ 1Program Studi Teknik Sipil, Fakultas Teknik Universitas Khairun, Ternate \\ ${ }^{2}$ Mahasiswa Teknik Sipil, Fakultas Teknik Universitas Khairun, Ternate \\ *Corresponding authors: e-mail: gaussmuhammad@gmail.com \\ Manuscript received: 19-02-2017 Revision accepted: 21-04-2017
}

\begin{abstract}
Abstrak
Speedboat merupakan salah satu moda yang mengbungkan pusat kota Ternate dengan pusat kota Tidore Kepulauan. Meningkatnya pelaku perjalanan menggunakan moda ini menuntut perlunya perhatian terhadap aspek kenyamanan dan keselamatan pengguna moda. Kondisi di lapangan menunjukkan bahwa moda speedboat beraktivitas pada siang maupun malam hari, pada berbagai cuaca dan mengangkut bukan hanya manusia namun juga barang. Penelitian ini bertujuan untuk menganalisis tingkat pelayanan speedboat menurut penilain pengguna moda menggunakan metode analisis Importance Performance Analysis (IPA). IPA digunakan untuk memetakan hubungan antara importance (kepentingan) dengan performance (kinerja) dari masing-masing atribut pelayanan menurut penilaian penumpang speedboat Ternate-Tidore. Tingkat pelayanan moda transportasi speedboat Ternate-Tidore menggunakan metode IPA didapatkan variabel yang memiliki kepentingan/Harapan yang tinggi namun pada kinerja/realita tidak cukup baik, yaitu variabel penerangan di malam hari, ketersediaan baju pelampung/life jacket dan ketersediaan kotak P3K. Sedangkan variabel yang dianggap kurang penting oleh penumpang, tetapi kinerjanya baik sehingga penumpang menganggap kinerja tersebut berlebihan, yaitu variabel layanan informasi dan tarif speedboat, ketersediaan pelontar .
\end{abstract}

Kata kunci - Speedboat, Moda Transportasi, Importance Performance Analysis

\begin{abstract}
Speedboat is one of transportation modes connecting the city central of Ternate to the city central of Tidore Island. The increase in travellers who use the mode requires attention on the aspect of comfort and safety of the mode users. Field condition indicates that speedboat mode starts active at noon and night in various weathers. The mode is not only transported people but also goods. The research aimed to analyze the speedboat service level based on the appraisal from the mode users using Importance Performance Analysis (IPA) method. IPA used to map the relationship between the importance and performance of each service attribute according to the appraisal of the passengers of Ternate-Tidore speedboat. The service level of Ternate-Tidore speedboat transportation mode using IPA method indicated that there were variables with high importance/expectation but less performance/reality, which were night lighting variable, the availability of life jacket and first aid box, whereas, variables considered as less important by the passengers but had good performance so that passengers regarded them as overwhelmed were information service variable, speedboat rate, and the availability of thrower.
\end{abstract}

Keywords - Speedboat, Transportation Mode, Importance Performance Analysis 


\section{TECHNO: Vol. 06 ( 01): 11-17, Mei 2017}

\section{PENDAHULUAN}

Transportasi mempunyai peranan penting dalam kehidupan manusia, karena transportasi mempunyai pengaruh besar terhadap perorangan, masyarakat, pembangunan ekonomi dan sosial politik suatu negara. Tanpa adanya transportasi sebagai sarana penunjang, tidak dapat diharapkan tercapainya hasil yang memuaskan dalam usaha pembangunan berbagai aspek dari suatu negara. Secara umum angkutan ini sendiri dapat didefinisikan sebagai pengembangan orang dan barang dari suatu tempat ke tempat yang lain dengan menggunakan kendaraan. Perangkutan diperlukan karena sumber kebutuhan manusia tidak terdapat disembarangan tempat. Sistem yang digunakan untuk mengangkut penumpang dan barang dengan menggunakan alat angkut tersebut dinamakan moda transportasi. (Mardiani: 2013). Beberapa fungsi transportasi, diantaranya 1) Untuk memudahkan aktifitas manusia dalam kehidupan sehari-hari. 2). Untuk melancarkan arus barang maupun arus manusia. 3). Untuk menunjang perkembangan pembangunan pada suatu daerah. dan 4). untuk menunjang perkembangan ekonomi dengan jasa angkutan.

Provinsi Maluku Utara merupakan daerah maritim yang sebagian besar wilayahnya terdiri dari pulau-pulau. Kota Tidore merupakan salah satu kota yang berada di Provinsi Maluku Utara yang memiliki hubungan sangat dekat dengan Kota Ternate dilihat dari letak geografis. Dengan berkembangnya pusat perdagangan jasa dan pendidikan, hal ini berdampak pada meningkatnya pergerakan masyarakat yang berimplikasi pada meningkatnya kebutuhan masyarakat akan sarana transportasi laut.

Penyeberangan laut merupakan satu-satunya terpenting yang menghubungkan antara Kota Ternate ke Kota Tidore. Tingginya peningkatan jasa angkutan penyeberangan mendorong pemerintah untuk lebih memperhatikan masalah kenyamanan dan keselamatan terutama pengembangan fasilitas baik untuk keselamatan penumpang maupun keselamatan speedboat. Apabila pelayanan yang tidak baik terhadap penumpang pengguna jasa speedboat dipelabuhan Bastiong maka penumpang akan merasa tidak aman dan nyaman. Melihat kondisi diatas, maka perlu adanya evaluasi kinerja pelayanan angkutan penyeberangan antar pulau sehingga nantinya ada keseimbangan antara jumlah kebutuhan (Demand) dengan tingkat pelayanan speedboat

\section{METODE PENELITIAN Jenis Penelitian}

Penelitian ini dilaksanakan di kota Ternate dan kota Tidore Kepulauan, untuk mengetahui persepsi pengguna moda digunakan kuisioner yang disebarkan ke pengguna speedboat. Penelitian ini melibatkan 100 responden dengan mempertimbangkan waktu, lokasi, umur, jenis kelamin, pekerjaan, penghasilan dan asal reseponden. Dilaksanakan selama satu minggu dengan waktu pengambilan yang berbeda-beda pula.

\section{Bahan dan Peralatan}

Bahan dan peralatan yang digunakan dalam penelitian adalah kuisioner yang dibagi dalam dua kelompok pertanyaan yang menyangkut karakteristik responden pengguna moda transportasi dan persepsi pengguna moda transportasi. Pertanyaan yang digunakan untuk mengetahui persepsi penumpang disusun berdasarkan peneltian sebelumnya yang sejenis dan divalidasi sehingga pertanyaan tersebut layak digunakan dalam kuisioner.

\section{Teknik Pengambilan Data}

Pengambilan data dilakukan dengan cara: 
1. Pengambilan data digunakan dengan cara turun langsung ke pelabuhan speedboat Bastiong Kota Ternate.

2. Pembagian kuisioner yaitu dengan membagikan kuesioner pada para penumpang untuk mengisi pertanyaan-pertanyaan didalam kuesioner sesuai dengan klasifikasi.

3. Data-data sekunder diperoleh langsung dari intansi pemerintah terkait yaitu BPS Kota Ternate serta Kota Tidore dan KUD Sadar Kota Tidore.

\section{Teknik Analisa Data}

Digunakan analisis kuadran untuk memetakan kinerja (realita) dan kepentingan (harapan) dari pengguna jasa speedboat terhadap beberapa indikator kualitas pelayanan yang mempengaruhi kepuasan pelanggan.

Berdasarkan hasil penilaian tingkat kepentingan dan penilaian kinerja maka akan dihasilkan suatu perhitungan menjadi tingkat kesesuaian antara tingkat kepentingan dan tingkat pelaksanaannya. Tingkat kesesuaian adalah hasil perbandingan skor kinerja dan skor kepentingan pengguna jasa angkutan penyeberangan speed boat.

Dalam penelitian ini terdapat dua variabel yang digunakan yaitu tingkat kinerja pelayanan yang dialami dan dinyatakan dengan $X$, serta tingkat harapan penumpang yang dinyatakan $Y$.

$$
T k i=\frac{X i}{Y i} \times 100 \%
$$

Dimana:

Tki $=$ Tingkat kesesuaian responden .

$\mathrm{Xi}=$ Skor penilaian kinerja.

$\mathrm{Yi}=$ Skor penilaian kepentingan pengguna jasa .

Selanjutnya sumbu mendatar $(X)$ akan diisi oleh skor tingkat kinerja/Realita sedangkan sumbu vertikal (Y) akan diisi oleh skor tingkat kepentingan/harapan. Untuk setiap faktor yang mempengaruhi penilaian pengguna jasa dengan menggunakan rumus:

$$
\begin{aligned}
& \bar{X}=\frac{\sum X i}{n} . \\
& \bar{Y}=\frac{\sum Y i}{n} \cdots
\end{aligned}
$$

Dimana:

$$
\begin{array}{ll}
\bar{X} & =\text { Rata-rata tingkat penilaian kinerja indikator ke-i. } \\
\bar{Y} & =\text { Rata-rata tingkat penilaian kepentingan/harapan indikator ke-i. } \\
\mathrm{n} & =\text { Jumlah responden. }
\end{array}
$$

Selanjutnya adalah menghitung rata-rata tingkat kepentingan dan kinerja untuk keseluruhan indikator, dengan rumus:

$$
\begin{aligned}
& \overline{\bar{X}}=\frac{\sum \overline{X l}}{k} . \\
& \overline{\bar{Y}}=\frac{\sum \overline{Y l}}{k} .
\end{aligned}
$$


Dimana:

$\overline{\bar{X}} \quad=$ total rata-rata tingkat penilaian kinerja atribut ke-i.

$\overline{\bar{Y}}=$ total rata-rata tingkat penilaian kepentingan/harapan atribut ke-i.

$\mathrm{k}=$ Jumlah pertanyaan dalam kuesioner.

Skor rata-rata tingkat penilaian kinerja dari responden selanjutnya akan ditempatkan pada diagram kartesius dengan sumbu mendatar (sumbu X) merupakan skor rata-rata tingkat penilaian kinerja $\bar{X}$ dan sumbu tegak (sumbu Y) adalah skor rata-rata tingkat penilaian kepentingan/harapan indikator $\bar{Y}$. Diagram kartesius ini akan dibagi menjadi empat (4) kuadran dengan perpotongan sumbunya merupakan nilai rata-rata total dari skor penilaian kinerja $\overline{\bar{X}}$ dan total skor penilaian kepentingan/harapan indikator $\overline{\bar{Y}}$. Diagram kartesius tersebut dapat dilihat pada Gambar 1.

Supranto (2006), menjelas bahwa pengertian dari masing-masing kuadran dijelaskan sebagai berikut:

1. Kuadran I (Prioritas utama), Kuadran ini merupakan indikator yang sangat mempengaruhi tingkat kepuasan pengguna jasa terhadap kinerja yang kondisinya tidak memuaskan dan perlu mendapat prioritas peningkatan.

2. Kuadran II (Pertahankan kinerja), Kuadran ini menunjukkan indikator yang mempengaruhi tingkat kepuasan pengguna jasa terhadap kinerja yang kondisinya telah memenuhi harapan dan perlu dipertahankan.

3. Kuadran III (Prioritas rendah), Kuadran ini menunjukkan indikator yang tidak begitu penting dalam memenuhi tingkat kepuasan pengguna jasa terhadap kinerja, yang pelaksanaannya dianggap kurang penting.

4. Kuadran IV (Berlebihan), Kuadran ini menunjukkan indikator yang tidak begitu penting dalam memenuhi tingkat kepuasan pengguna jasa terhadap kinerja yang dalam pelaksanaanya pengguna jasa menerima pelayanan lebih dari apa yang diharapkan sehingga tidak menjadi prioritas perbaikan (berlebihan).

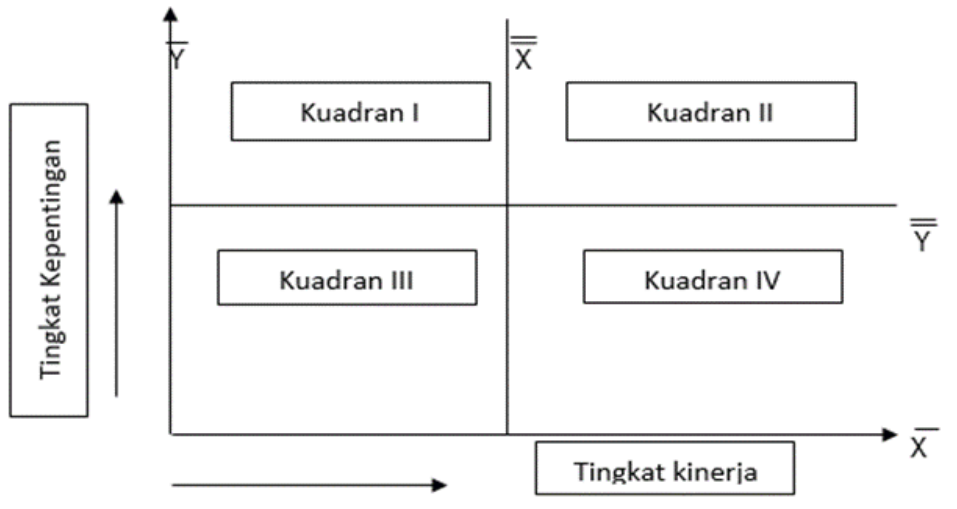

Gambar 1. Diagram kartesius analisis kepentingan dan kinerja

\section{Analisa Data}

Metode IPA digunakan untuk memetakan hubungan antara kepentingan dengan kinerja dari masing-masing atribut pelayanan menurut penilaian pengguna speedboat Ternate-Tidore. Uji T-test dan Analisis Of Variance (Anova), untuk mengetahui rata-rata persepsi/penilaian dari penumpang speedboat Ternate-Tidore berdasarkan karateristik dari pengguna jasa. Analisis 
Korelasi, untuk mengetahui korelasi antara masing-masing karateristik dari penumpang speedboat Ternate-Tidore.

\section{HASIL DAN PEMBAHASAN}

\section{Karakteristik responden}

Karakteristik responden pengguna moda speedboat di tunjukkan pada Gambar 2 sampai dengan Gambar 5.

1. Jenis kelamin

Berdasarkan hasil penelitian yang dilakukan diketahui bahwa sebagian besar responden speed boat berjenis kelamin laki-laki sebanyak $60 \%$ dan perempuan sebesar $40 \%$. Adapun tabel dan diagram lingkar dari responden berdasarkan jenis kelamin seperti pada gambar 2 .

2. Umur

Berdasarkan hasil penelitian diketahui bahwa sebagian besar umur dari responden yang melakukan perjalanan speedboat berusia 20-25 tahun sebesar 19\%, usia 26-30 tahun sebesar $21 \%$, usia $31-40$ tahun sebesar 39\%, berusia $41-50$ tahun sebesar15\% dan dengan usia lebih besar 51 tahun sebesar $6 \%$.

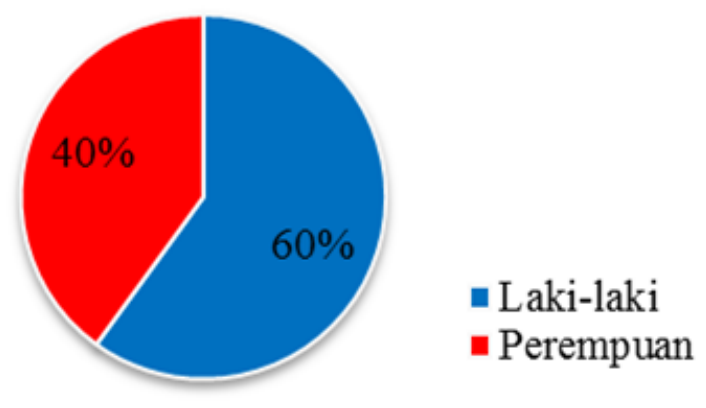

Gambar 2. Karakteristik responden berdasarkan jenis kelamin

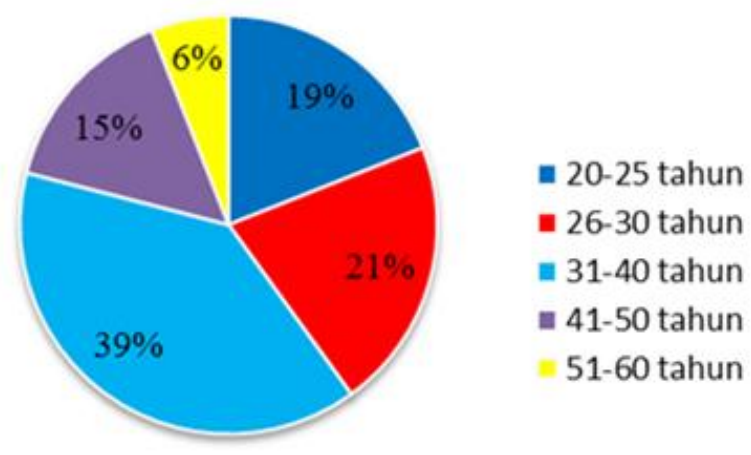

Gambar 3. Responden berdasarkan umur 


\section{TECHNO: Vol. 06 ( 01): 11-17, Mei 2017}

3. Pendidikan terakhir

Berdasarkan hasil penelitian yang dilakukan diketahui bahwa sebagian besar responden speedboat berpendidikan terakhir SMA sebesar 43\%, kemudian S1/S2/S3 sebesar 43\%, Diploma sebesar 12\%, SMP dan SD sebesar 1\%.

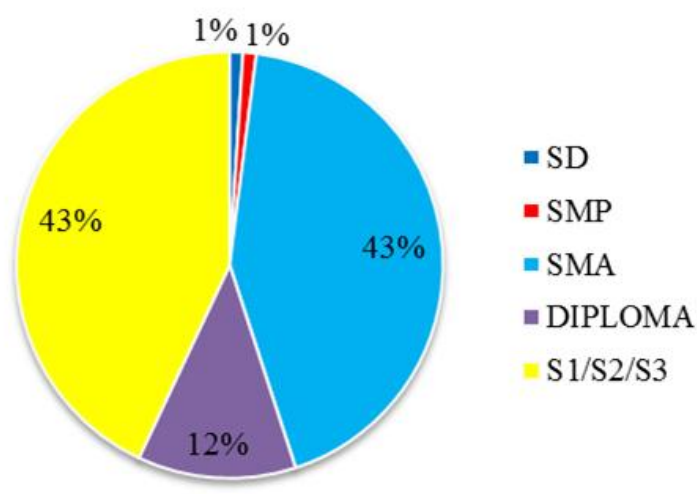

Gambar 4. Karakteristik responden berdasarkan pendidikan

\section{Pekerjaan}

Berdasarkan penelitian diketahui pekerjaan darii responden yang menggunakan speedboat bekerja sebagai PNS/TNI/POLRI sebesar $43 \%$, pelajar/mahasiswa sebesar $6 \%$, pegawai swasta/BUMN sebesar $14 \%$, wiraswasta sebesar $21 \%$ dan lainnya sebesar $16 \%$.

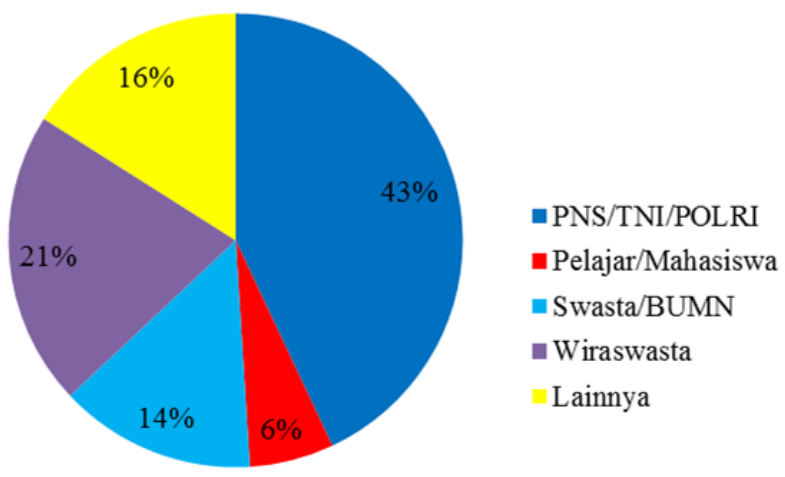

Gambar 5. Karakteristik responden berdasarkan pekerjaan

5. Penghasilan

Berdasarkan hasil penelitian yang dilakukan diketahui penghasilan bulanan responden yang menggunakan speed boat <Rp.1.000.000 ada sebanyak $12 \%$, penghasilan Rp.1.000.000-2.000.000 sebanyak 24\%, Rp. 3.000.000-Rp.4.000.000 sebanyak 25\%, dengan penghasilan >Rp.4.000.000 sebesar $19 \%$ dan lainnya sebanyak $20 \%$. 


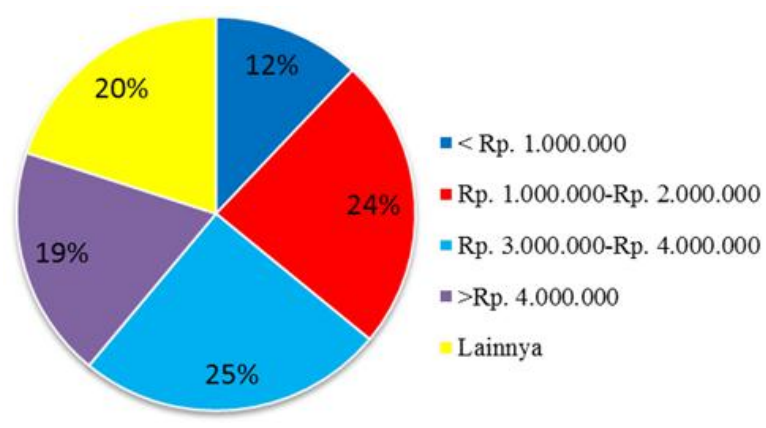

Gambar 6. Karakteristik responden berdasarkan pendapatan

6. Berdasarkan Tujuan Perjalanan Responden

Berdasarkan penelitian diketahui bahwa tujuan dari responden penumpang speedboat dengan tujuan perjalanan dinas sejumlah $43 \%$, dengan tujuan bisnis sebanyak $9 \%$, rekreasi/liburan sebanyak $4 \%$, dengan tujuan untuk bertemu keluarga sebanyak $28 \%$ dan tujuan Lainnya sebanyak $16 \%$.

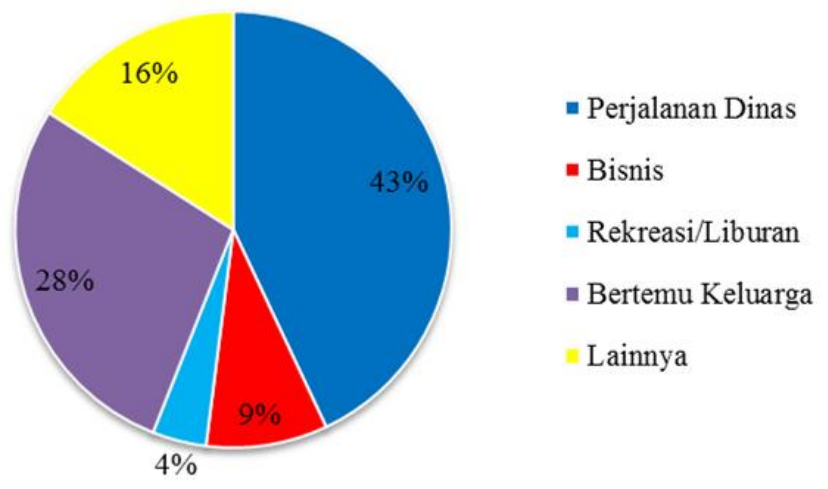

Gambar 7. Karakteristik responden berdasarkan tujuan perjalanan

Tabel 3 menunjukkan hasil pengujian properties agregat kasar di mana :pengujian kadar air 0,5\%, kadar lumpur 1,1\%, kondisi lepas 1,8 kg/ltr, kondisi padat 1,7 kg/ltr, berat jenis kering oven $2,29 \%$, berat jenis semu $2,35 \%$ dan keausan agregat $24 \%$. Ini memperlihatkan bahwa properties agregat kasar telah memenuhi spesifikasi, kecual kadar lumpur yang tidak sesuai dengan spesifikasi sehingga sebelum material agregat kasar digunakan perlu dicuci guna untuk menghilangkan lumpur yang ada pada agregat kasar. 


\section{Analisis importance performance analysis}

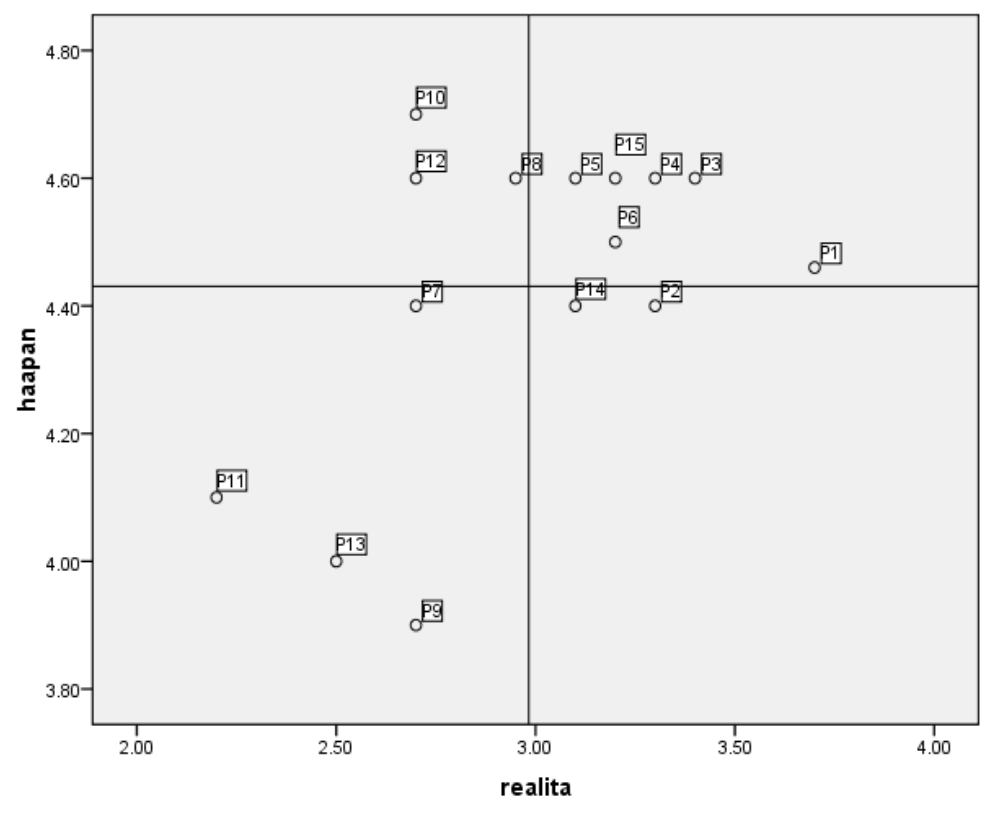

Gambar 8. Hubungan realita dan harapan metode IPA

Pengukuran IPA dijabarkan ke dalam diagram kartesius yang terlihat pada Gambar 8. Pada gambar 4.8 menunjukkan bahwa, sumbu $X$ dan sumbu Y. Sumbu $X$ merupakan tingkat kinerja (realita) dan sumbu Y merupakan tingkat kepentingan (harapan) yang dikelompokkan menjadi 4 kuadran. Ada variabel yang ditunjukkan dalam diagram kartesius adalah 1. Kebersihan, 2. Layanan informasi dan tarif, 3. Kenyamanan tempat duduk didalam speedboat, 4. Sikap penyedia jasa dalam melayani penumpang, 5. Penindakan tegas petugas bagi yang melanggar, 6. Area sirkulasi udara didalam speedboat, 7. Tempat penitipan barang, 8 . Penerangan di malam hari, 9. Ketersediaan alat navigasi kompas/GPS, 10. Ketersediaan baju pelampung/life jacket, 11. Ketersediaan alat pemadam kebakaran/aper foam, 12. Ketersediaan kotak P3K, 13. Ketersediaan perangkat pesawat radio, 14. Ketersediaan pelontar tali dan 15. Ketersediaan isyarat marabahaya.

\section{SIMPULAN}

Berdasarkan hasil analisis tingkat pelayanan moda speedboat Ternate-Tidore menggunakan metode IPA dapat disimpulkan

1. Variabel yang memiliki kepentingan/Harapan yang tinggi namun pada kinerja/realita tidak cukup baik, adalah 1. Penerangan di malam hari (8), 2. Ketersediaan baju pelampung/life jacket (10) dan 3. Ketersediaan kotak P3K (12).

2. Variabel yang dianggap kurang penting oleh penumpang, tetapi kinerjanya baik sehingga penumpang menganggap kinerja tersebut berlebihan, adalah 1. Layanan informasi dan tarif speed boat (2) dan 2. Ketersediaan pelontar tali (14). 


\section{DAFTAR PUSTAKA}

Abdurahman, Tursina. 2011. Analisis Kinerja Pelayanan Kapal Ferry Terhadap Penumpang Ternate-Sofifi (Skripsi). Ternate: Fakultas Teknik Universitas Khairun.

Dedi Wiriyawan, Adi Aspina Nur, Pengaruh Efeltifitas Pelayanan Terhadap Kepuasan Konsumen Pada Pelabuhan Speedboat Kayan II Tanjung Selor, Fakultas Ekonomi Uiversitas Kaltara.

Lumban Gaol, Sabrina. 2008. Evaluasi Pola Pergerakan Orang Dan Barang Dengan Moda Transportasi Air : Studi Kasus : dari dan ke kota Balige (Skripsi). Sumatera Utara: Teknik Sipil Universitas Sumatera Utara.

Mardiani, Cahirul Anwar, Mufti Amir Sultan, 2013. Model Probabilitas Pemilihan Moda Kapal Ferry Dan Speed Boat Rute Ternate-Tidore, Sipilsains, Vol.03 No. 06. Pp:33-40.

Mardikawati Woro, Farida Naili, Pebgaruh Nilai Pelanggan dan Kualitas Layanan Terhadap Loyalitas Pelanggan, Melalui Kepuasan Pelanggan Pada Pelanggan BUS Efisiensi, Studi PO Efisiensi Jurusan Yogyakarta-Cilacap.

Melfa Yola, Duwi Budianto, Analis Kepuasan Konsumen Terhadap Kualitas Pelayanan dan Harga Produk Pada Supermarket Dengan Menggunakan Metode Importance Performance Analys (IPA), Program Studi Teknik Industri, Universitas Islam Negeri Sultan Syarif Kasim Riau.

M.Rani, Kartika Sari. 2016. Studi Kinerja Kapal Ferry Bastiong Ternate (Ternate-Sofifi) (Skripsi). Ternate: Fakultas Teknik Universitas Khairun.

Moh Noh. 2005. Metode Penelitian. Bogor: Ghalia Indonesia.

Nusa Sembayang, Ruslan Effendie, Studi Evaluasi Tingkat Pelayanan dan Tarif Moda Angkutan Sungai Speedboat Studi Kasus: Jalur Angkutan Sungai Kecamatan Kurun ke Kota Palangkaraya, Kalimantan Tengah, Teknik Sipil, ITN Malang.

Ofyar Z, Tamim. 2000. Perencanaan dan Pemodelan Transportasi. Bandung: ITB.

Triatmodjo, Bambang. 2009. Perencanaan Pelabuhan. Yogyakarta: Beta Offsed. 